\title{
Hallgrímskirkja, ReykJavík \\ A Late Example of Expressionist \\ Church Architecture
}

\author{
Aurél Benárd \\ Institute of Architecture, Ybl Miklós Faculty of Architecture, \\ Szent István University, Budapest, Hungary \\ Benard.Aurel@ybl.szie.hu
}

\begin{abstract}
Reykjavik's largest church, Hallgrimskirkja has become a symbol and an important part of Icelandic national identity. This edifice result of conscious planning process with its location and form reinforce its national significance. Its impact derives from several elements. Buildings symbolizing the identity of communities are usually quite conservative in form. Hallgrimskirkja, however, has distinct individual features that stem from architect Guðjón Samúelsson's aspiration to express the nation's identity in a specific architectural form.
\end{abstract}

Keywords: Expressionist architecture, Iceland, Art Deco, national architecture, Lutheran Church, nature and architecture

\section{INTRODUCTION}

Seated on a hill, this distinctive building rules over the townscape of Iceland's capital. The picture-perfect sight of its characteristic spire perched atop a steeple is visible from every corner of the city. Reykjavik's Lutheran cathedral is the second highest structure [1] on the island of Iceland. Being both a landmark and „Stadtkrone”, it is one of the main attractions of the city. The Hallgrímskirkja has dominated the city skyline since the 1980s and the story of its construction is closely related to the 20th-century history of Iceland's independence.

\section{THE URBAN CONTEXT OF THE CHURCH}

\subsection{Iceland}

Iceland is an island country in the North Atlantic. In terms of the geologic timescale, it is a comparatively young volcanic island that was created along the fault line between the Eurasian and the North American tectonic plates providing its characteristic natural frame of volcanic formations. The territory of the island is slightly bigger than that of Hungary with its northern edge reaching the Arctic Circle. Its harsh climate is moderated by the Gulf Stream. The island has been inhabited since the 9th century, its early Medieval population is of Viking and Celtic origins from Norway and Scotland.

${ }^{2}$ Stadtkrone: (english: city crown) an idea of Bruno Taut german expressionist architect from 1919 for the symbolic cultural - sacral centre of the modern city 
Culturally, Iceland belongs to Scandinavia: during the 19th century it was controlled by the Danish Crown but its social changes also connect the country to the Nordic culture. Due to the belated rise of the bourgeoisie. Iceland's prosperity appeared only at the beginning of the 20th century, much later than in most European societies.

Iceland's autonomy preceding the World War Two brought about a period of economic prosperity accelerating Reykjavik's growth and development as well.

\subsection{Reykjavík}

As legend has it, Iceland's capital and biggest settlement, Reykjavik (meaning Smokey Bay) was founded on the south-eastern edge of the island by the Norwegian Ingolfur Arnarson in 870 .

The city used to be a fishing village up until the 19th century with the earlier historical centres of the country situated further inland. However, not even those major centres (Pingvellir, Skálholt) could qualify as towns.

Reykjavik got its primacy due to the favourable location of its harbour. The industrial revolution also made its way to Iceland, at a time when it was still an overlordship of Denmark. This coincided with the spread of national movements in the 19th century, which also reached Iceland, although - unlike in many countries in mainland Europe - the idea of creating a unified nation did not become a central widely-held notion, primarily due to the prevailing harsh climate and extreme poverty.

Conscious urban planning and development date back only to the end of the 19th and the beginning of the 20th centuries. The city centre itself was comprised of essentially nothing more than two stone houses: the cathedral and the modest building of the parliament, in addition to an 18th-century administrative building and two other houses that belonged to a school. Residential houses and farm buildings of the era were typically built of wood. [2]

\subsubsection{Skólavörðuholt - the eastern hill}

The heart and oldest part of the city stretches between the two hills of the peninsula, in a valley lying roughly in a north-south direction. The valley itself opens onto the old harbour of the city while its other end is guarded by a natural lake. The urbanization started much later than in major European cities. The idea of constructing a religious-cultural centre for Reykjavik that would serve as the architectural representation of the nation on the top of one of the hills straddling the city arose only at the beginning of the previous century.

Economic growth was also accompanied by heightened national sentiments. The emblematic artist of Iceland at the time was sculptor Einar Jónsson [3] (May 11, 1874 - October 18, 1954)

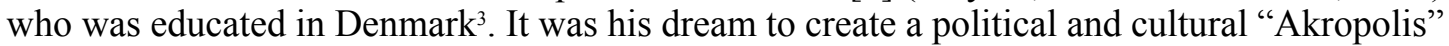
for an independent Iceland, an citadel erected on Skólavörðuholt, the eastern hill of the city. In 1916, as the first step of this project, he built a characteristic, statue-like museum the first floor of which was occupied by his own apartment. The plans based on Einar Jónsson's ideas were drawn by architect Einar Erlendsson. Later, he extended the building with more studios.

$\overline{{ }^{3} \text { Royal Danish Academy of Fine Arts, Copenhagen, } 1896-1899}$ 
The structure was inspired by the Arts and Crafts movement but it also echoes the influence of Scottish National Romanticism, especially that of the designs by Charles Rennie Macintosh.

Its distinctive feature is the stairwell that includes a spiral staircase encased in a massive Doric pillar. Previously, the barren hilltop had only been decorated by a small belvedere. [4]

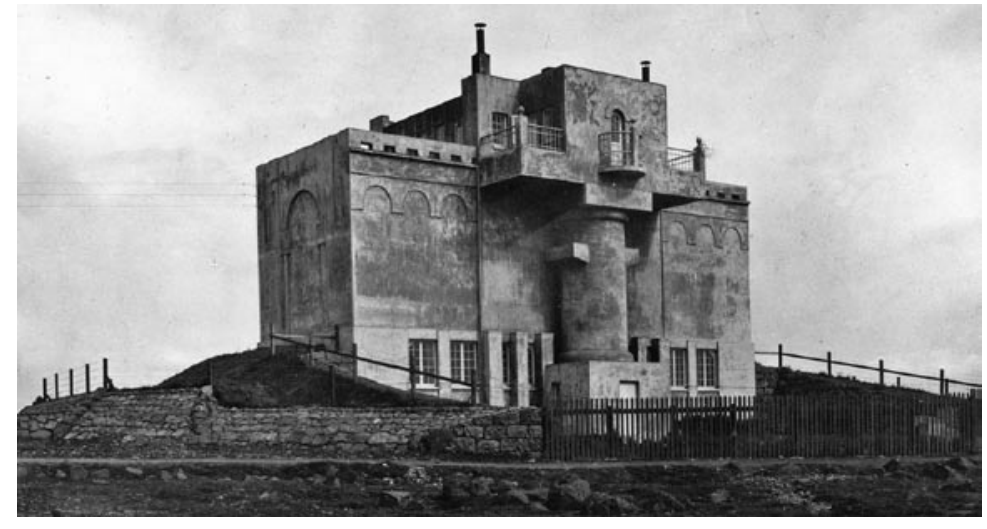

Figure 1. Einar Jónsson’s house on the Skólavörduholt 1916

Einar Jónsson's house marked out the symbolic significance of the area and in the same year, in 1916, architect Guðjón Samúelsson drew up plans for the Skólavörðuholt, styling a church with an asymmetrically placed tower and a longitudinal main volume displaying the features of the Scandinavian-Finnish National Romantic style against the backdrop of houses similar to that of Einar's. The church bears strong resemblance to Lars Sonck's Tampere Cathedral [5, p. 36]. In 1924 , as the newly appointed "state architect of Iceland"s, he planned a development layout for the hilltop which displayed a square surrounded by cultural institutes including Einar Jónsson's museum as well [5, p. 16]. The structures designating the spatial boundaries of the square comprise a school, a university, a museum, a congregation hall, a "house for art lovers" and residential buildings in addition to a gate that opens onto the square at the mouth of Skólavörðustigur, the road heading up the hill.

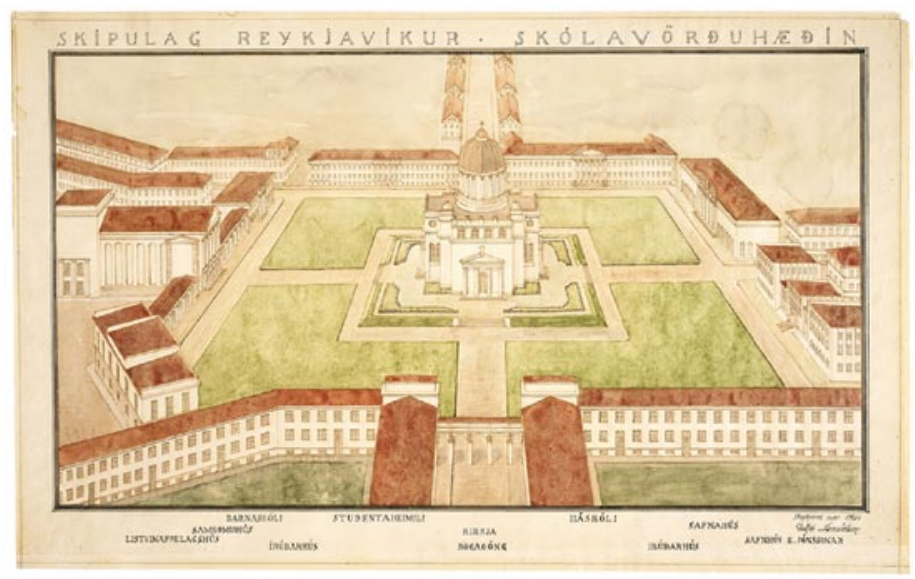

Figure 2. Gudjón’s Idea for the Skólavörðuholt, 1924., 
Along the axis of Skólavörðustigur, in the middle of the square stands a domed church erected on a Greek cross design and bearing Classicist features

\subsubsection{Landakot - the western hill}

The realization of the plan gathered momentum as a result of important developments taking place at the same time on Landakot, the western height of the city.

Landakot saw the consecration of the then biggest church of the country in 1929. Before the Basilika Krists Konungs, (i.e. The Basilica of Christ the King or Landakotskirkja for short) was complete, a hospital and a school had also been constructed on this western hilltop funded by French Franciscan and Carmelite nuns. The Neo-Gothic mission church was built within a year on a design by Guðjón Samúelsson who made the above mentioned plans for the church and square to be constructed on Skólavörðuholt.

The Roman Catholic church became a landmark dominating the skyline of contemporary Reykjavik even though only 4\% of the population of modern Iceland is Roman Catholic in contrast with $70 \%$ of the inhabitants that belong to the Lutheran Church (as of 2017) [6]. Furthermore, at the time of its construction, in 1920, the size of the Catholic denomination added up to a mere 67 persons, it was just short of 200 in 1930 (191 persons) and grew to 335 persons in 1940. [7]

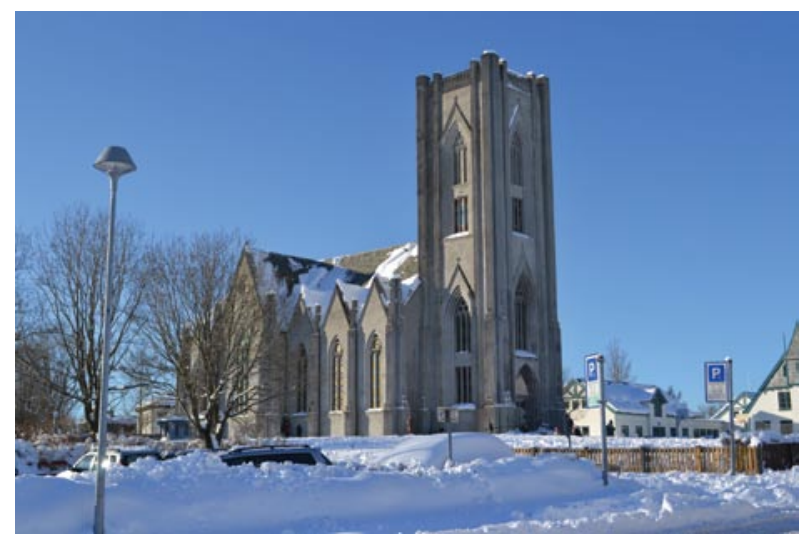

Figure 3. Landakotskirkja.

Nevertheless, Landakot's Church not only strengthened the idea of turning the hill into a cultural and symbolic place but also shifted the focus of its role from being a "cultural citadel" to becoming a religious center.

\section{THE HISTORY OF HALLGRÍMSKIRKJA}

\subsection{Early history}

The construction of Hallgrímskirkja, the church to be built on Skólavörðuholt, was supported by the government. As it is the case in Denmark, Lutheranism is the official religion in Iceland as well. The church was named after Hallgrímur Petursson, a pastor and poet from the 17th century who is probably held in greater reverence across Iceland than Martin Luther, the founder of the church. 
In 1929, when the bishopric was led by Jón Helgason, an architectural design competition was launched to invite proposals for the construction of Hallgrímskirkja.

Architect Águst Pálsson designed a classical Gothic Revival structure with a single tower while Hafliða Johannsson construction-carpenter's naive model shows a Neo-Romanesque church with two towers but - inconsistently - slightly big openings. Águst Pálsson architect was awarded an amount of 1,000 crowns, while Hafliða Johannsson construction-carpenter and Ágúst Hákonárson painter received a prize of 500 crowns each. $[5$, p. 13]

In the meantime, the square was given a new feature that had an important role in strengthening identity and shaping the surrounding space: in 1930, a statue of the Viking explorer, Leifur Eiríkson was erected along the axis of Skólavörðustígur. ${ }^{6}$

\subsection{Guðjón Samúelsson}

Architect Guðjón Samúelsson resumed working on Hallgrímskirkja in 1937. By that time, he had already designed several important public buildings in his capacity as state architect. ${ }^{7}$ He was sponsored by Jónas Jónsson, a person of great influence over contemporary political life in Iceland, who later not only founded a party but also went on to serve as Minister for Justice and Religion from 1927 to 1932 [8].

As an architect, Guðjón Samúelsson was also heavily engaged in urban planning and development. He was born on 16 April, 1887 in Kirkjubæjarhreppi, the southern Vestur-Skaftafellst province of Iceland as the son of Samúel Jónsson construction-carpenter and Marget Jónsdóttir.

He was raised in Reykjavik where his parents built a house at 35 Skólavörðustígur (not far from the future Hallgrímskirkja) and where he spent a lot of time in his later years as well.

Guðjón became a qualified construction-carpenter in 1908, and later graduated from the Royal Danish Academy of Fine Arts, School of Architecture ${ }^{8}$ in Copenhagen with a degree in Architecture. He also completed a special programme to become state architect (húsameistari ríkisins in Icelandic), a title and position which he was awarded immediately upon finishing the course and which he kept until the end of his life.

Guðjón was certainly not cut out for becoming the type of architect who insists on using a single hallmark style throughout his career. Turning away from Neoclassicism, he discovered functionalism and Romanticism, making an attempt at developing a distinctively Icelandic architectural style. While the influence of the Icelandic turf house tradition is visible on his Héraðsskólinn school building in Laugarvatn (1928), his designs also reflect the island's omnipresent natural formations, the columnar basalt flows that appear in their purest form in the columns of Hallgrímskirkja. ${ }^{9}$

\footnotetext{
${ }^{6}$ The statue created by sculptor Alexander Stirling Calder was a present to Iceland from the United States to mark the millennial celebrations of the foundation of the parliament in 930. Leifur Eiríkson was the first European to reach the American continent on his voyage to Greenland at the turn of the 10th century.

${ }^{7}$ http://kirkjan.is/hallgrimskirkja/soknin/

${ }^{8}$ Kunstakademiets Architect Skole

${ }^{9}$ Guðjón Samúelsson's major designs: National Bank (1918-24, Neoclassical); Eimskip maritime transportation company's headquarters (1919); Landakotskirkja (1929); Hallgrímskirkja (1945-86); Memory Clinic University Hospital;National Theatre (1929-50, the unfinished building was used as a warehouse by the British army); the main building of the University of Iceland (1940); the development plan for Akureyri (1929); Akureyrarkirkja (1940); Hotel City Borg, Reykjavík; and the Sundhöllin swimming pool (1937).
} 
Guðjón was extremely passionate about architecture. He was the father of the first development plan of Iceland in 1921, and his plan for the development of the town of Akureyri in 1927 included the idea of dividing the commercial and industrial zones of the city from the residential areas, which was a rather progressive thought at the time.

Many of his buildings, especially their vast horizontal surfaces have become damaged due to their exposure to a bleak climate and the low quality of concrete, the main construction material. Nevertheless, they are considered to be the most remarkable structures of the country on account of their appearance formed with such sensitivity.

Guðjón passed away on 25 April, 1950 in Reykjavik. [9]

\section{GUĐJÓN SAMUELSSON'S CHURCH}

The construction of the religious site on Skólavörðuholt soon became a national concern and the parliament also supported the idea that Lutherans making up the majority of the population should have a new church holding the rank of cathedral. In 1940, with Sigurgeir Sigurðsson serving as the Bishop of Iceland, the single parish of Reykjavik was divided into three parishes. This division led to the establishment of the Hallgrímsson congregation in charge of the construction, which was immediately halted by the outbreak of World War II.

During the British invasion, Skólavörðuholt, the planned site of the church became a military camp $^{10}$. Following the war, the construction restarted as a slow process. The level below the sanctuary was completed between 1945 and 1948 and was opened for congregants with the military barracks made from corrugated steel sheets still surrounding the site. The next major step was taken in 1974. From that year onwards, services were held in the congregational room in the southern wing adjoining the tower.

Finally, the cathedral was consecrated on 26 October, 1986, on the day following the 312th anniversary of the death of Hallgrímur Pétursson who lent his name to the church. [10]

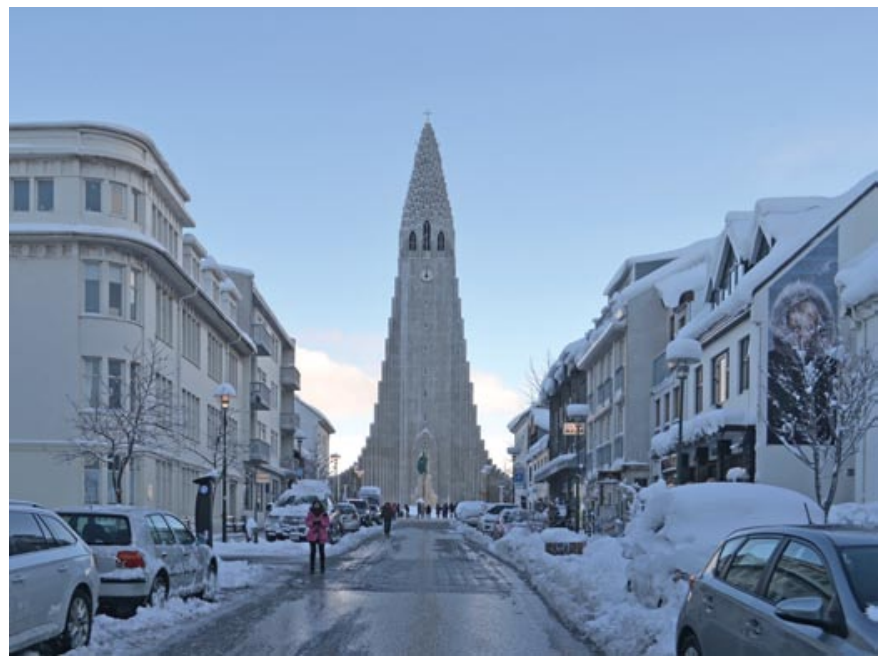

Figure 4. The Hallgrimskirkja

$\overline{{ }^{10} \text { Skipton Camp 1940-1958. }}$ 


\subsection{Personal antecedents and inspiration; local, national, religious and social framework}

The success of Landakot had probably contributed to the fact that Guðjón was commissioned to design the church. Landakot's Church was his first major religious structure, and a confidently formed, conservative edifice. Later he built several other churches, including, for example, the expressively shaped Akureyrakirkja in 1940 with two towers and the smaller, Art Deco-inspired Modernist Laugarneskirkja in Reykjavik (1949).

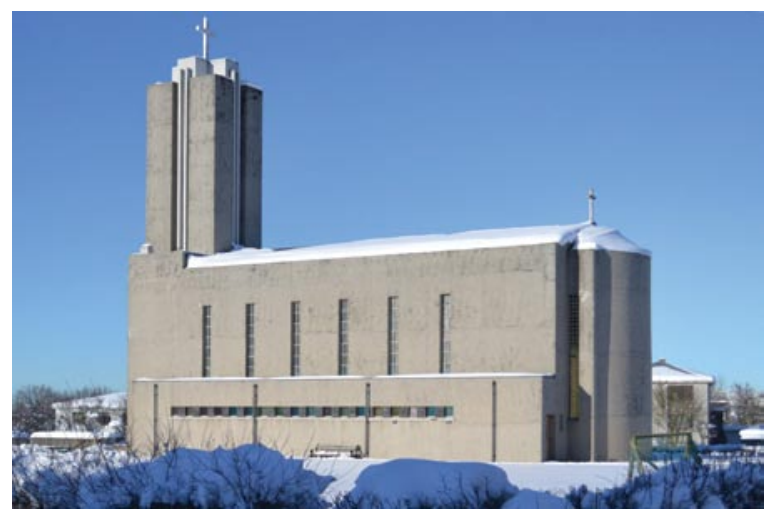

Figure 5. Laugarneskirkja (1949)

Guðjón Samúelsson aimed at creating a national, Icelandic architektural idiom. His previous designs had already borne references to the traditional turf houses [12] of Iceland as it can be seen on the Héraðsskólinn building (1928). A more successful attempt is represented by Svartifoss which evokes the fantastic natural formations of the basalt organs ${ }^{11}$ In the case of Landakot, the clustered columns characteristic of the Gothic style are reinterpreted reflecting the polygonal geometric patterns of basalt organ pipes which appear as a dominant motif on Hallgrímskirkja.

Later this pattern is applied only as a decorative element at the portals of the late Art Deco building of the National Theatre, although from an architectural perspective it is ambiguous due to their likeness to stalactites or to the cellular structure of Muqarnas ${ }^{12}$. Nevertheless, their geometry retains that of the „basalt pipes” as they are cut like diamonds.

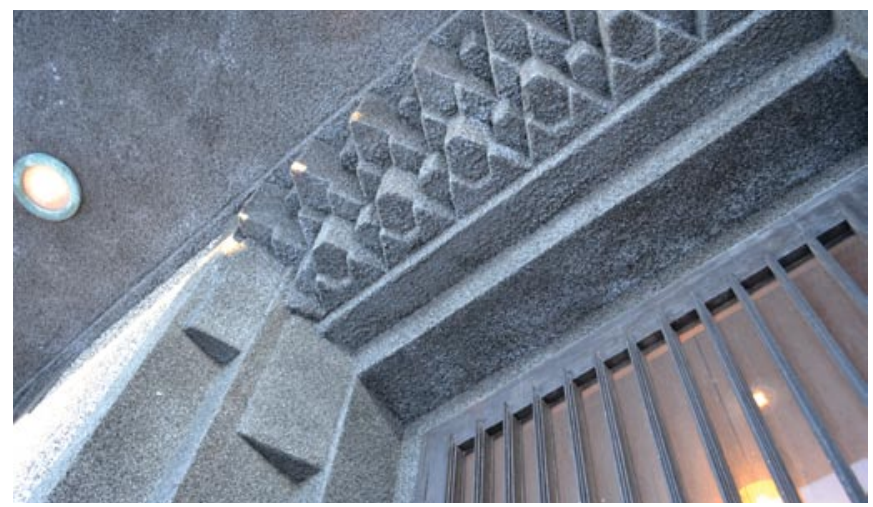

Figure 6. The detail of the National Theater's gate

\footnotetext{
" charasteric organ pipe-like features of vulcanic stones

${ }^{12}$ stalactite vaults
} 


\subsection{Regional and global precedents}

An early work of Guðjón, the National Bank was strongly influenced by Scandinavian neo-Classicism of the 1920's, which suited well for the function and the desired effect of the building. But he also drew from Art Nouveau and its Scandinavian version that can be detected in his Reykjavíkurapótek inspired by Eliel Saarinen. Although Scottish National Romanticism became dominant only in his later designs, it is still important with regard to Hallgrímskirja because of his plan to include the only existing building on the hilltop, the earlier mentioned exciting studio-museum-house of sculptor Einar Jónsson into the spatial boundaries delineating the square.

\subsubsection{Expressionism}

The most important influence on the church originates form of Expressionist architecture which had become a dominant movement, especially in Germany, by the time Guðjón was finishing his studies. The most powerful Expressionist church of the era is the Lutheran church on Hohenzollerplatz in Berlin ${ }^{13}$ and although it is a brick building, its façade can easily be related to that of Hallgrímskirkja.

Expressionist architecture had given birth to another characteristic building in Denmark as well. Grundtvigskirken ${ }^{14}$ was built based on the design by father and son, Peder Vilhelm Jensen Klint and Kaare Klint in 1921-26, but the plan submitted to the competition had been prepared in 1913 when Guðjón was still at university in Copenhagen.

Grundtvigskirken is probably a direct predecessor of Hallgrímskirkja (Kaare Klint, the son was the same age as Guðjón). It was also built of brick but being an earlier structure, it shows a strong influence of Historicism. The nave represents a structure reminiscent of the Neo-Gothic architecture of the era of 19th-century Romanticism. The church stands along the axes of the square flanked by residential buildings erected in $1924-36 .{ }^{15}[11$, p. 29]

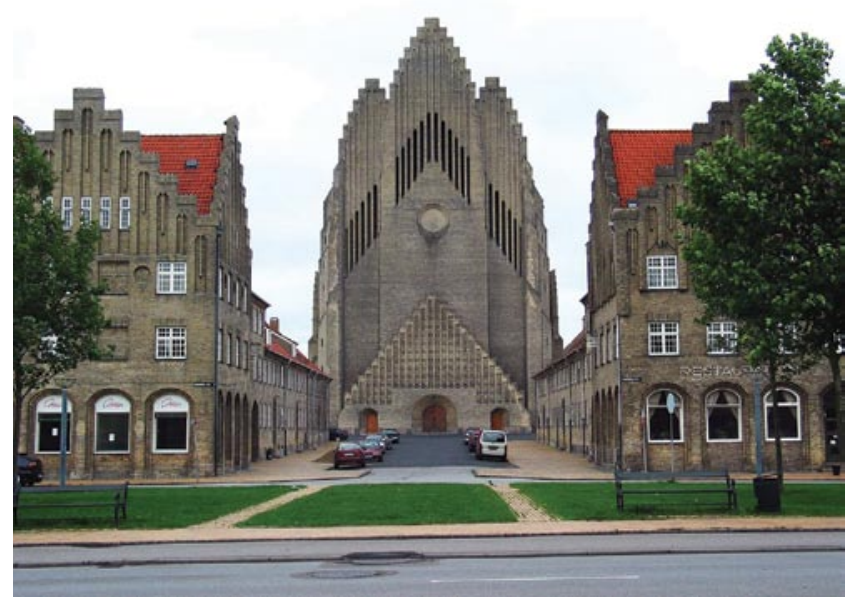

Figure 7. The Grundtvigskirken Copenhagen

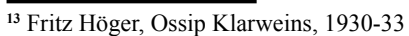

${ }^{14}$ Grundtvig's Memorial Church

${ }^{15}$ also Guðjón Samúelsson planned in 1924 a layout for the hilltop church which displayed a square surrounded by cultural institutes, see Figure 2.
} 


\subsubsection{The Danish church architecture and the brick}

It is important here to make a brief reference to the origins of Danish church architecture, the primary source of which was German Brick Gothic. The Gothic style arrived in Denmark through German influences transmitted by the trading cities of the Hanseatic League. The typical features of this particular German version became widespread in Denmark as well including the material used, the simplicity of the way it was shaped, the flat wall surfaces only articulated by allettes and its massive blocks. The two major characteristic representatives are St. Canute's Cathedral in Odense (12-15th c.) and the Carmelite Priory in Helsingør (1480-1500). [11, p. 10]

The use of bricks contributes to the building's simplicity. Characteristic structural elements that are to loose the bulk of Gothic buildings fall off - such as the buttress and flying buttress system crowned by turrets that jut out from the main body of the edifice. The same is true of the typical ornaments such as carved stone gables, traceries, crockets, stone cross finials, gargoyles, etc. Thus, Brick Gothic buildings become a homogenous, monolithic block that is animated only by the patterns in the material and the texture of the courses. A local development is the elongation of the traditional crow-stepped gables.

An earlier version of Guðjón's plan shows a more striking resemblance to Grundtvigskirken, as the design features three towers and a façade almost as wide as that of its Danish predecessor while the envelope of the zigzag contour of the stepped gable of the main façade is concave, almost like a parabolic curve turned upside down. This early plan for Hallgrímskirkja shows a similar characteristic with a more reserved parabolic curve that opens downwards. However, this motion later turned into its opposite gesture, probably due to the increased demand for a bigger service area which in turn necessitated a bigger ground-space, thus the side wings could not be concealed by the buttresses of the tower. Therefore, the parabolic curve was turned and it became convex, resulting in a dynamic upward movement. Nevertheless, the parabolic curve itself remained, so did the curve enveloping the zigzag contour of the façade. However, the zigzag line here does not come from the traditions of brick architecture since Hallgrímskirkja is completely made of concrete. Its distinctive contour is simply formed by horizontally cutting off the top of the basalt organ pipes along the envelope.

This change might have been inspired by the persuasive Expressionist works of Einar Jónsson. In one of his paintings the uplifted arms of the central figure of Christ are supported by a block of basalt organ pipes rising towards the sky ${ }^{16}$.

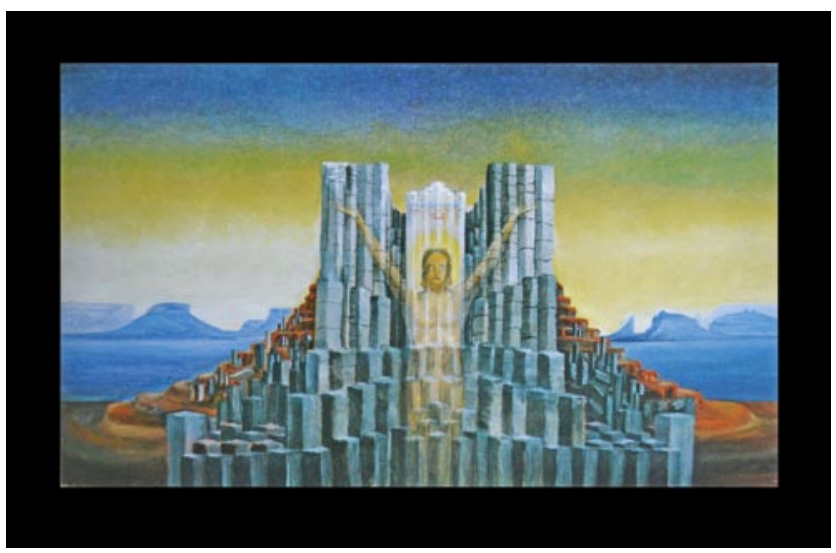

Figure 8. Einar, Jónsson: Lofgjörðin Frysta

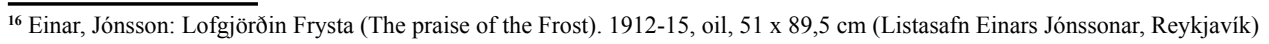


The result leaves us with a dynamic impression though the original impetus is somewhat halted by the pyramid of the spire. An even greater dynamism characterizes the pedestal of the Leif Erikson statue erected earlier in front of the main entrance to the church which might have inspired the styling of the façade.

\subsubsection{Concret as a national building material}

It did not take Iceland very long to adopt reinforced concrete as its national building material. Its use in constructing residential houses started already at the beginning of the 20th century. Since the island's rich resources of volcanic rock cannot compensate for the lack of trees, concrete came as a natural choice, primarily due to its resistance to harsh weather. Thus, the whole structure of Hallgrímskirja was also made of concrete. This led to homogenous surfaces on its walls and pillars clad in greyish-white plaster complete with clustered columns that are unrealistically slim and walls as thin as if they were mere surfaces.

\section{ARTICULATION OF SPACE AND ITS ELEMENTS}

The church stands in the middle of the square laid out on its axes. The square is almost a regular rectangle forming an angle with the primary coordinate system of the city, thus Frakkastígur running into it on its northern side follows the main axis of the city while Skólaförðustígur that leads up to the main entrance forms part of the new internal network of the city.

The essentially conservative structure of the longitudinally laid out chatedral is composed of three major parts: the distinctively formed body of the tower with side wings for the service facilities, the much more conservative nave and the cylindrical body of the sanctuary that seems to be an additional element. Visually, these three parts are clearly different and separated from each other, almost in a didactic way offering neither an organic connection between them nor a well-designed solution for their connection. As a result, the building gives the impression of being awkward and fragmented reflecting the centurieslong inherent problem of the western Christian church architecture related to the matter of how to shape the massive body of vast buildings.

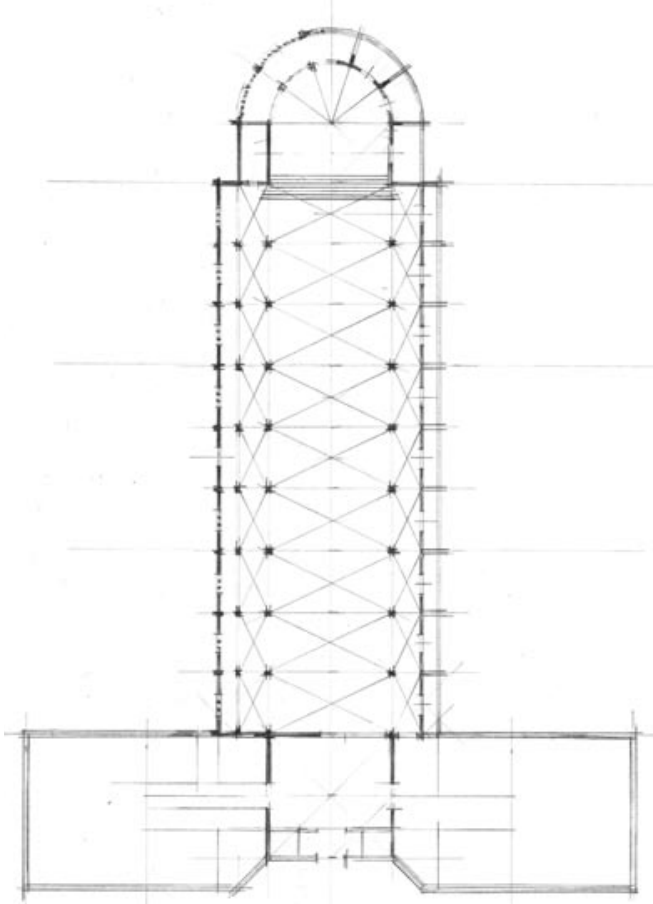

Figure 9. The sketch of the ground plan 


\subsection{The tower and its wings}

The church is dominated by its 73-meter high tower that at the same time is the highest structure in the city. Due to the tower, the frontal façade oriented to the north-west offers the main view of the church. The façade features a central tower flanked by two anthropomorphic side wings whose stepped rooflines glide down smoothly following the concave parabolic curve described earlier. They have a twofold function. On the one hand, they hide the service facilities. On the other hand, their role is to solve the architectural problem of the tower's connection to the longitudinal volume of the edifice. These wings display a dynamic gesture only when viewed from the front of the building since their base is an almost regular rectangle. However, this is concealed by the façade's surface, which is shaped into basalt organ pipes built of monolithic reinforced concrete. The spaces between the pipes are not just solid blank blocks, instead they are interspersed with narrow ribbons of fixed panel glass windows whose frames can be easily hidden. This tracery-like design, however, can only be admired when the lights inside are turned on once dusk has come. The body of the tower is a rectangular cuboid topped with a pyramidal spire. The four corners of the tower are supported by stepped buttresses again in the form of clustered basalt organ pipes. The buttresses on the façade run diagonally forming a 45-degree angle with the plane of the façade also embracing the frontal surfaces of the side wings described above. This geometry lends the façade its characteristic anthropomorphic gesture (see Figure 9.). However, the buttresses supporting the two rear corners of the tower enclose a right angle with the main axis of the church leaving a slightly insecure impression in the side view. The top story of the tower is decorated by three pointed-arch openings on each side capped with a spire employing tracery design. When lit at night from the inside, it is as if it were crowned by a shining hat. This feature can be understood as the solid reinterpretation of the stone tracery network of Gothic spires (e.g. Freiburg im Breisgau). The Freiburg Minster itself may also be considered as a predecessor due to it being the archetype of single-towered Gothic churches. This also goes to show that the primary inspiration does not come from the Gothic cathedrals typical of the Ile de France region. [12, p. 142] The spire is decorated with a cross. (In addition to the cross, the spire also hosts other technical equipment since the tower of Hallgrímskirkja is used as a TV tower as well.)

\subsection{The nave}

The nave is also characterized by a triple segmentation as reflected in its 3 bay by 3 bay length. The main longitudinal body is essentially a five-aisled structure with an equal-width cross section. This is an explicitly historicist element of the building. Its three central naves are reminiscent of German Gothic three-naved-churches, a feature highlighted by the regular ribbed Gothic cross vaults rippling through the ceiling. The intersections of the vault crowns are not decorated by bosses but they are much higher up than the vault keys of the transverse arches. This central three-naved space is supported on each side by much lower and narrow aisles covered with a flat ceiling. The two aisles on the sides are separated from the central ones by flat-top openings. The side walls of the protruding hall display slim pointed-arch windows. The proportion of walls and windows, the blank glass panels of the windows make the inner space transparent and clear, lacking the transcendent atmosphere of the Middle Ages. Although Landakotskirkja was built with a transept and the earlier plans of Hallgrímskirkja also included one, finally it was erected without the arms of the cross. Otherwise, the structure of the hall inside the main longitudinal body in these two churches are identical except for the aisles of Hallgrímskirkja on its two sides that are quite small anyway. The original design, however, 
contained a very different idea. On one of the earlier versions of the first plan the aisles were supposed to have a gallery along their walls as befitted a Lutheran cathedral and as it can also be seen inside the 19th-century Reykjavik Cathedral. The decision to ignore the gallery may be explained by two considerations. First, the size of the congregation was quite small compared to the dimensions of the cathedral, thus the main focus was placed on the structure's symbolic strength, meaning and significance. Second, Hallgrímskirkja serves as the main Anglican church of Reykjavik and a space without an encircling gallery is more easily embraced by the different traditions of the Church of England. The final result justifies the decision: an organically unified, almost ethereal space has been constructed which shines in homogenous bluish light when lit by the sun.

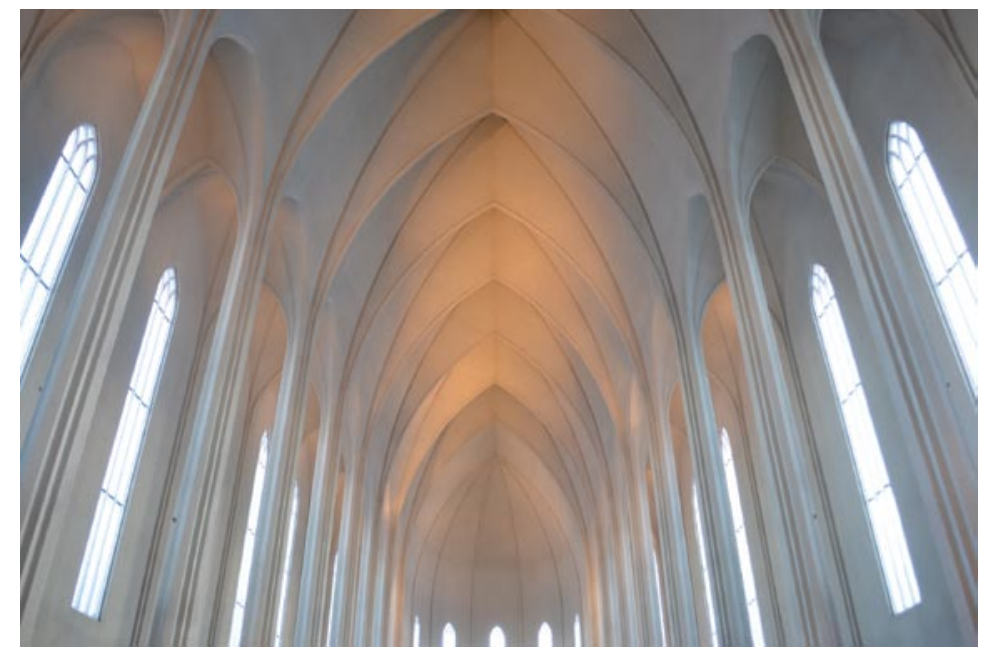

Figure 10. The vaulting of the nave.

The lower aisles on the sides are built with small, almost square-shaped windows that are arranged in groups of three in each bay. This setting, however, has only a practical function without a stronger influence on the spatial structure. The aisles also feature two additional functional elements, though they look somewhat alien to the simple tone of the church. One of them are the barrel vaults decorated lengthwise by furrows that function as a suspended ceiling covering the flat roof of the aisles. The other is the steel panels hiding the radiators but they also display the same greyish-white plaster that covers the walls. Their contour follows a zigzag line that lends a rippling effect to the recessed structure of the sidewalls.

\subsection{The spacial analogie: a sacred Lutheran space in the mid-20th century}

The interior of Hallgrímskirkja revokes the inner space of the main Lutheran church of Bonn, Germany (Evangelische Kreuzkirche, [15] originally built as a Neo-Gothic structure in the 19th century (1871). It was seriously damaged in World War II and its reconstruction (1951-54) roughly coincided with the main construction period of Hallgrímskirkja. The aisles of the three-aisled hall church are wider, a feature obviously due to the original design concept of the church. However, the outer walls of the aisles are built with a gallery supported by steel columns forming a low corridor along the edges of the inner space. This gives a sense of intimacy that is quite similar to the effect created by the aisles of Hallgrímskirkja. 
The vault of the church in Bonn is new, built in the mid-20th century, but its geometry follows the structure of Gothic stellar vaults albeit without ribs having only edges to mark the ridges between the panels. This makes it look as if it was folded giving the impression of an origami design. However, its light, undecorated surface lit through colourless vertical windows provides for an ethereal inner atmosphere similar to that of Hallgrímskirkja. ${ }^{17}$ No direct connection could be detected between the churches though. Their similarity is probably only due to the spirit of the age that captured the essence of the sacred, the holiness of Lutheran space in the same historicist embrace. ${ }^{18}$

\subsection{The sanctuary}

A characteristic feature of the massive church is the sanctuary. Its astounding appearance surprises only those who walk around the vast body of the building, a move which does not come to one naturally because of the long distances and the long side wings leaning against the main facade that place the focus on the front of the edifice and the square laid out in front of it.

The astonishing outer shape is not echoed in the inner space as the sanctuary joins the NeoGothic nave in conservative a manner. The shimmer that appears in the main longitudinal body of the church becomes brighter here with the tall pointed arch windows shining a direct light on the sanctuary. The windows are not stained thus the power of pure light can freely manifest itself on a sunny day.

The regular cross vault of the nave is connected to the ribbed vault ceiling of the sanctuary by a short section covered with a pointed barrel vault. The vault of the sanctuary itself though looks more like a pointed half-dome segmented by radial ribs offering a more transparent and less mystical scenery than the vault structure of Gothic sanctuaries. In fact, the geometry of the barrel vault and half-dome evoke the space structure of Romanesque architecture. The windows of the sanctuary are similar to those of the main edifice but slightly smaller and instead of being placed on the second layer of the shell of the church they are built into the primary layer that is in the walls that run along and close the elongated lines of the row of columns in the nave.

The cross section of the three central naves gives a dynamic impression just like pseudo three-naved-churches with the apex being much higher up in the nave than in the aisles on both sides resulting in a relatively low clerestory when it reaches the sanctuary. This low clerestory carries the base from which the simplified vault of the sanctuary arises.

This geometry allows the sanctuary windows to approximate the size of the windows in the main edifice bringing about a dramatic effect. This is enhanced by the elevation of the sanctuary the floor of which is raised by seven steps under the triumphal arch. Behind the flattopped openings under the slim and tall windows of the sanctuary there is a low ambulatory with proportions reminiscent of the two aisles of the three naves. Similarly, its windows form an almost regular square but with nine windows in each panel - the triple-base number system occurring again - the opening becomes a horizontal row of windows making for a much lighter space. Thus, this bright ambulatory spectacularly accentuates the solemnity of the sanctuary.

The way the exterior mass of the church is shaped is out of harmony with its Neo-Gothic design elements. Hence it appears as a separate, self-contained additional piece whose precedent

\footnotetext{
${ }^{17}$ An other analogy: Sankt Petri kyrka in Malmö, in restored form

${ }^{18}$ The only known link between the two structures is that the organ in Reykjavik completed in 1992 was built by craftsmen from Bonn.
} 
can be found in the Church of our Lady (Frue Kirke) ${ }^{19}[12$, p. 24] in Copenhagen. The geometry of Frue Kirke lacks the dynamism of Hallgrímskirkja though. Instead, it radiates classicist tranquillity. A more contemporary analogy may be detected in Helsinki's Kallio Church (Lars Sonck, 1912) where the sanctuary looks cylindrical but stands adjacent to the base of the tower looming above the choir in a semicircle as if being attached like an independent body [5, p. 36]. It's historical antecedents were the Lady Chapels ${ }^{20}$ of the gotical sanctuary.

Viewed from the outside, the sanctuary of Hallgrímskirkja also seems to be cylindrical, although it is indeed a column ending in a half cylinder that rests on a drum of a longer diameter. This drum was the first part of the church that was built and it was used as a chapel as early as 1948. [6, p. 37]

The cylindrical impression of the exterior of the sanctuary stems from the roof of the altar which is an expressively shaped spire composed of concave and convex curves that form the pointed apex of this surface of revolution made of concrete. The shape of the spire puts a secondary, vertical accent - the primary being the tower itself - to this section of the church building.

In the case of Frue Kirke, the cylindrically shaped tambour also has a dominant role but here the cylinder is taller and firmly topped with the cornice which in turn is crowned by a lower drum with a regular half-dome perching on it. The underlying idea is obviously quite similar, however. The impression created by structural elements added this way is more in line with the Neo-Classicist than the Expressionist style.

The distinctive form of the sanctuary evokes the shape of Viking war helmets, another feature highlighting Guðjón's quest for tools that could give birth to a distinctively Icelandic architecture supporting also the self-identification of the nation. This can also be understood as a kind of self-reflection, a reaction to the orthodox design of Landakotskirkja where the sanctuary and the ambulatory received a regular vaults in line with the traditions of the Catholic Church. In contrast, the roof of the sanctuary of Hallgrímskirkja echoes the pagan origins of national traditions. The common characters of heathen legends such as trolls and goblins are important figures in the minds of people even today with a profound influence on the worldview of Icelanders.

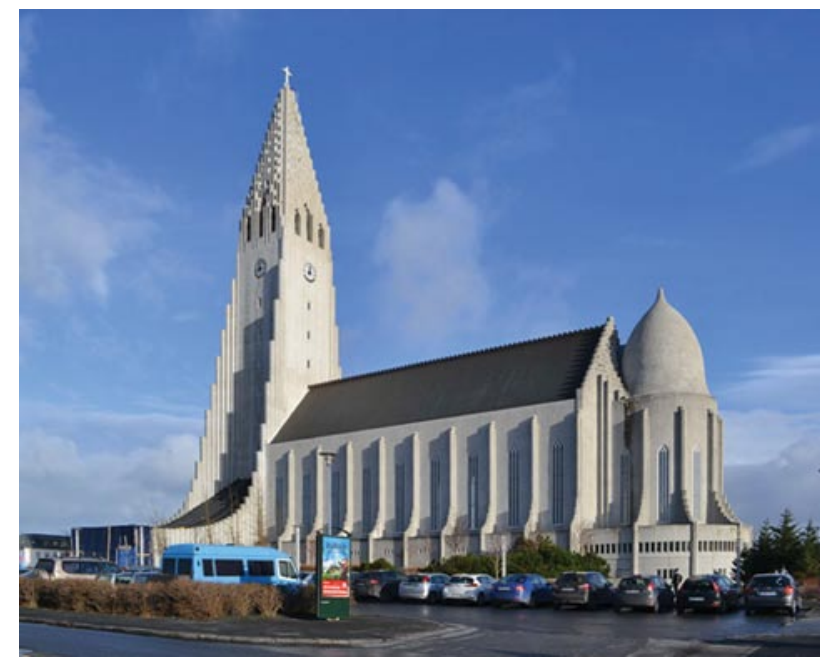

Figure 11. The Halllgrimskirkja south view with the Sanctuary

\footnotetext{
${ }^{19}$ Designed by architect Christian Frederik Hansen in the Neoclassical style, 1811-1829

${ }^{20}$ See for example: Canterbury Cathedtal, Turku Cathedral
} 


\subsection{The third national symbol}

This is the third element in the building that indicates Guðjón's intention to display national symbols on his emblematic structures in a move to create national architecture. The helmet is attached to the end of the longitudinal part of the building through a distorted surface which again features the fragmented geometry of basalt organ pipes. The spire of the tower is also cloaked in a similarly and intentionally fragmented surface.

\subsection{Related fields of art}

As usual for Lutheran communities, the congregation has a very conscious relationship with related fields of art. Within church art, music is the most important field including a vibrant scene of choir performances, organ concerts and music festivals. In addition to this strong Lutheran tradition, the narthex regularly hosts fine art exhibitions.

With regard to works of art directly related to the building itself, two main groups need to be mentioned. The church is decorated with artworks by pre-eminent Icelandic artists, for example Einar Jónsson's tiny bronze piece dedicated to Hallgrimúr Pétursson or Leif Kaldal's liturgical objects. Beside these works of art placed in space, there are other elements in a more organic connection with the structure made by present-day artist, Leif Breiðfjörður. He is credited with the pulpit, the baptismal font (2001), the entrance of the narthex and the main gate of the church with the rectangular lunette and the windows above the entrance (2010).

The main entrance reflects a unified design concept. Its central motif is the quatrefoil on the bronze gates which also appears on the glass window but there it is less visible since inside it is hidden by the organ while from the outside it can be seen only when lit at night. Both the window and bronze gate display elements from Christian iconography. The rectangular moulding above the gate is decorated by a bronze plaque with a poem by Hallgrímur Petursson inscribed on it. The first line reads as „Unto God's House...”. The red colour in the mosaic of the quatrefoil symbolizes the blood of Jesus. [6, pp. 138-145]

\section{SUMMARY}

\subsection{The architecture as an element of national identity}

Finally, Guðjón Samúelsson's architecture has become a pillar of Icelandic national identity. His role is similar to that of Antoní Gaudí in Catalonia, or, more explicitly, to that of Jože Plečnik in Slovenia. He truly became the „state architect” of Iceland. However, his works are much more diverse than the designs by either of the above mentioned architects, thus he did not create such a unified world as his European- Mediterranean colleagues. During his career that spanned a period of several generations he was influenced by many different styles and probably the single motif that connects his designs is reinforced concrete, the local building material.

In Guðjón Samúelsson's architecture one can discover two major styles and aspirations talán: Although classical Modernism did not touch him deeply, the influence of Secessioninspired Art Deco is quite pronounced in several of his works. His relationship to classical Modern architecture makes him similar to Jože Plečnik and also to Dominicus Böhm. 
The closest manifestation of the principles of Modernism that emphasize function and objectivity appears on his Siedlung-type (council housing estate) residential buildings.

The other profound influence on Guðjón's work, the world of Expressionist architecture born in Germany, also circumvents Modernism proper, and this is what essentially defined Hallgrímskirkja. Sculptor Einar Jónsson's intriguing expressionist art might have also played a crucial role in this development. The elements that endow Guðjón's buildings with specific national characteristics appear along these two major artistic ambitions.

\subsection{The significance of Hallgrímskirkja}

Due to the crawling construction process, the finishing touches on Hallgrímskirkja were added in the revival era of Expressionism in the mid-20th-century. Though probably completely independent of Hallgrímskirkja, a similar geometry appears on a church in Rome (Chiesa di Santa Maria Madre del Redentore) [16].

The design of the Lutheran cathedral has had a liberating effect on Iceland's 20th-century church architecture which had an essentially intensive and Scandinavian nature since its inception. Examples include among others the airy and iconic shape of Kópavogskirkja, Kópavogur (1958-1963) [17].

Guðjón's aspirations towards creating national architecture found an organic continuation in the Harpa Concert Hall and Conference Centre erected as a new cultural institution in the old harbour. ${ }^{21}$ Despite the fact that it was designed by a Danish firm, Henning Larsen Architects - in co-operation with Danish-Icelandic artist Olafur Eliasson and Batteríið Architects [17] -, it still reflects Iceland's characteristic natural formations. The vast façade overlooking the city is composed of glass hexagonal prisms that give the impression of a two-dimensional surface when viewed from the harbour. Interspersed with a few coloured glass sheets, it is reminiscent of the membranes of insect wings. The interior's monumental space is enhanced by the fair-face concrete walls that are coloured basalt black. This results in a sombre and solemn atmosphere but recalls the natural bed the island rests on at the same time presenting concrete as a traditional, noble and the national building material.

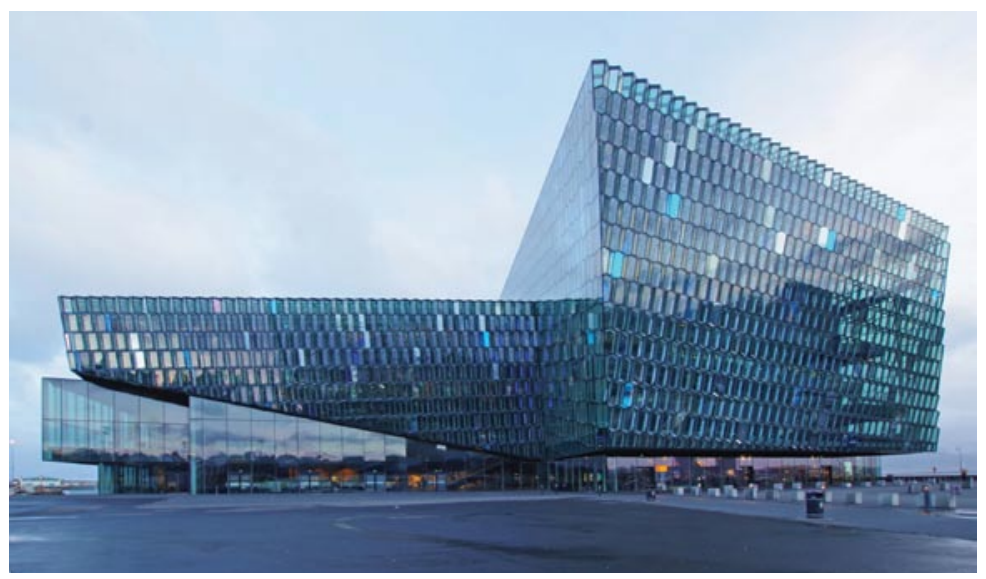

Figure 12. Harpa Concert Hall and Conference Centre

$\overline{21}$ 2007-2009, though construction was interrupted by the 2008 economic crisis. 


\section{REFERENCES}

[1] M. S. Helgason, Seven interesting facts about one of Reykjavik's best known landmarks, Hallgrimskirkja church, 2015.

[2] H. R. BÁRĐASON, Island - Porträt des Landes und Volkes, Reykjavík : Published by Hjálmar R. Bárðason, 1982.

[3] D. G. Finnbogason, Einar Jónsson Myndaskáld, Reykjavík: Listasafn Einars Jónssonar, 1982.

[4] „The Einar Jonssón Museum,” [Online]. Available: http://www.lej.is/en/museum/history/. [05 08 2017].

[5] E. NAGY, Mai finn építészet, Budapest: Műszaki Könyvkiadó, 1976.

[6] S. PÁLSSON, Mínum drottni till Pakklætis - Saga Hallgrímskirkju, Hallgrímskirkja, Reykjavík: Hallgrímskirkja, 2015.

[7] Hagstófa Ísland, Populations by religious and life stance organizations 1998-2017.

[8] Hagstófa Ísland, Roman Catholics in Iceland.

[9] E. Helgason, THE MASTER BUILDER, THE MINISTER AND THE CHURCH WE USED TO THINK WAS UGLY, Reykjavík, 2011.

[10] E. Helgason, THE MASTER BUILDER, THE MINISTER AND THE CHURCH WE USED TO THINK WAS UGLY, Reykjavík, 2011.

[11] „Um Hallgrímskirkju,” [Online]. Available: http://kirkjan.is/hallgrimskirkja/soknin/. [05 08 2017].

[12] B. G. BJöRnsson, Íslenskur menningararfur - Stóru torfbaernir, Reykjavík: Salka, 2013.

[13] E. NAGY, Dánia építészete [Danish Architecture], Budapest: Corvina Kiadó, 1977.

[14] A. Sódor, Az építészet története - Gótika, L. Judit, Szerk., Budapest: Terc Kereskedelmi és Szolgáltató Kft., 2013.

[15] „Kreuzkirche (Bonn),” [Online]. Available:https://de.wikipedia.org/wiki/Kreuzkirche_(Bonn). [ 0508 2017].

[16] „Chiesa di Santa Maria Madre del Redentore,”[Online]. Available: https://it.wikipedia.org/wiki/Chiesa_di_Santa_Maria _Madre_del_Redentore. [05 08 2017].

[17] „Kópavogskirkja,” [Online]. Available:https://en.wikipedia.org/wiki/K\%C3\%B3pavogskirkja. [ 05082017$].$

[18] Text description provided by the architects, „Harpa Concert Hall and Conference Centre / Henning Larsen Architects \& Batteriid Architects," archdaily, 26072011.

\section{Illustrations and Sources}

Figure 1. Einar Jónsson's house on the Skólavörduholt 1916 https://www.lej.is/uploads/images/Gallery/home/BG3.jpg (201708 05)

Figure 2. Gudjón's Idea for the Skólavörðuholt, 1924., via S. PÁLSSON, Mínum drottni till bakklætis - Saga Hallgrímskirkju, Hallgrímskirkja, Reykjavík: Hallgrímskirkja, 2015. p. 16.

Figure 3. Landakotskirkja (author's photo, 19/02/2017)

Figure 4. The Hallgrimskirkja (author's photo, 19/02/2017)

Figure 5. Laugarneskirkja (1949) (author's photo, 19/02/2017)

Figure 6. The detail of the National Theater's gate (author's photo, 19/02/2017)

Figure 7. Grundtvigskirken Copenhagen https://upload.wikimedia.org/wikipedia/commons/thumb/7/78/Grundtvigskirkenvest-2005-3.jpg/1280px-Grundtvigskirken-vest-2005-3.jpg (05.08.2017.)

Figure 8. Einar, Jónsson: Lofgjörðin Frysta (The praise of the Frost). 1912-15, oil, 51 x 89,5 cm (Listasafn Einars Jónssonar, Reykjavík)

Figure 9. The sketch of the ground plan (author's sketch)

Figure 10. The vaulting of the nave (author's photo, 19/02/2017)

Figure 11. The Halllgrimskirkja south view with the Sanctuary (author's photo, 19/02/2017)

Figure 12. Harpa Concert Hall and Conference Centre (Photo: Nagy, G. D. 19/02/2017) 